\title{
Hot Pres Particle Board Characteristics Using Tanin Adhesive Result Rawwood Extraction
}

\author{
Siswanto*, Nurul Widji Triana \\ Chemical Engineering Department, Technology Faculty, Universitas Pembangunan Nasional “Veteran” \\ Jawa Timur, Indonesia
}

${ }^{*}$ Corresponding author:

E-mail:

siswantomoenandar@yahoo.com

\begin{abstract}
Wood powder waste is very abundant if it is allowed to rot, which can pollute the environment, therefore wood powder can be made as a material for making particleboard. As an adhesive for the manufacture of particleboard, tannins from the extraction of mangrove bark are needed. According to Paridah and Musgrave 2006, the tannins content in mangrove bark reaches $26 \%$. According to Hamidah 2006 mangrove bark that is dried or crushed contains an average of $20-30 \%$ tannins and the content of these tannins is quite high and is very good for use in various kinds of industries. The purpose of this research is to find the optimum temperature of pressing and the amount of added tannins to obtain strong particleboard following SNI. The use of tannins is expected to be an environmentally adhesive alternative. The preparation of this particleboard is done by preparing the raw materials, extracting tannin from mangrove bark using a solvent of $96 \%$ ethanol at a temperature of $70{ }^{\circ} \mathrm{C}$ for 3 hours, after that it is continued with the process of making particleboard by mixing between wood powder and tannins with variations of $20 \%, 25 \%, 30 \%$ and $35 \%$ with previously had been mixed with formaldehyde $2 \%$ of the weight of wood powder before pressing. Mold is made with a size of $20 \times 20 \mathrm{~cm}$ were then pressed using a hot press with a temperature of $110^{\circ} \mathrm{C}, 120^{\circ} \mathrm{C}, 130^{\circ} \mathrm{C}$, and $140^{\circ} \mathrm{C}$. The result obtained was tested for the expected tensile compressive strength values according to SNI where the resulting particleboard can be used for household and industrial purposes. Tannins added as much as $30 \%$ produce the best MOR value of $7,76 \mathrm{~kg} \mathrm{f} / \mathrm{cm}^{2}$ while the pressing temperature of $120{ }^{\circ} \mathrm{C}$ result in the best MOR value of $7,66 \mathrm{~kg} \mathrm{f} / \mathrm{cm}^{2}$
\end{abstract}

Keywords: Wood powder, tannins, hot press, particleboard

\section{Introduction}

At this time in Indonesia, the potential for wood waste is very much, this wood powder waste I usually produced as a by-product of industrial wood processes such as plywood and furniture. So far sawdust has contaminated the environment if it was allowed to rot. Therefore, this wood sawdust waste must be minimized by using it for various purposes including as material for making particleboard. Particleboard is a type of reconstituted wood its manufacture still relies on conventional wood from natural forests whose existence is already limited (Iskandar, 2013).

Particleboard is generally a flat shape with a relatively long, wide, and thin size so it's called a panel (Fathanah, 2013). Tannins are very complex polyphenol compounds, due to the presence of phenol groups in tannins, tannins can react with formaldehyde to form a thermosetting product that can be used as an adhesive (Danarto et al., 2011). Most plants contain tannins but only a few contain tannins namely Acacia bark, pine bark, mangrove bark, and mahoni bark. Natural tannins are classified into hydrolysis tannins and condensed tannins (Suseno, 2014). According to Paridah and Musgrave (2006), the tannins content in mangrove bark reaches $26 \%$ and mangrove bark that is dried on average contains $20-30 \%$ tannins and the tannins content is quite high and very good for use in various kind of industries (Hamidah, 2006). Using organic compounds as parti-

\section{How to cite:}

Siswanto, \& Triana, N. W. (2021). Hot pres particle board characteristics using tanin adhesive result rawwood extraction. $5^{\text {th }}$ International Seminar of Research Month 2020. NST Proceedings. pages 30-37. doi: 10.11594/ nstp.2021.0906 
cleboard adhesives such as tannins can reduce the phenol-formaldehyde resin in the particleboard industry because phenol is a non-renewable raw material. The use of tannins as an organic adhesive can reduce the emission of formaldehyde, a poisonous gas that can cause cancer and respiratory system disorders. Suhendry (2017) explains that the higher the formaldehyde concentration used the faster the gelatinization time. Gelatinization time is the time required by the tannin mixture with formaldehyde to shape gel after boiled a few minutes in the hot water at $90{ }^{\circ} \mathrm{C}$. This happens because the high viscosity causes rapid clotting to occur, this rapid clotting causes the tannins to harden immediately so that the gelatinization time is shorter and the gelatinization time affects the port life on adhesive. The thermosetting adhesive is a permanent hardening adhesive, a thermosetting type hardening process through a chemical reaction accelerated by heat or a catalyst (Oka, 2005). Thermosetting adhesive will harden when hot pressed and can't return to form a liquid (Ruhendry, 2013).

Thermosetting polymers have cross-link that is easily formed when heated that make the polymer hard. The more cross-link on this polymer the more prone to breaking, when the polymer is heated a second time it will cause damage or breakage between the polymer chains. Overheating will cause some crosslink bonds and the polymer its self is degraded, thermosetting polymers are generally tougher and stronger than thermoplastics and have better dimensional stability, also thermosetting polymer has hard and rigid properties when heated, they harden are difficult to recycle, can't dissolve in any solvent, if heat will be hard (Lempang, 2016). Several previous researchers have made particle board as Sumadiwangsa (1986) researching mangrove powder as particleboard adhesive with variable press temperature and grain size mangrove powder, from this research it's concluded that the higher temperature of the press used will increase the physical and mechanical properties of the resulting particle board, while the grain size of the mangrove powder doesn't significantly affect the physical and mechanical properties of the particleboard it produces.

Danarto et al. (2011) utilized tannins from mangrove bark as a substitute for phenol groups in phenol-formaldehyde resin with variable concentrations of solvent and tannins powder. From this study, it was concluded that the higher the ethanol concentration would affect the yield produced and the modification of tannins in phenol-formaldehyde resin to form phenol-formaldehyde tannins would improve the shear strength. Fathanah (2013) examined the manufacture of particleboard from empty palm fruit bunches with acacia and gambier peel adhesive with a variable ratio of adhesive to oil empty bunches. From this research, it can be concluded that the value of the compressive firmness of the particle board in dry conditions increases with the addition of adhesive but in wet conditions, it decreases the tensile and compressive strength of the particle board due to the hydrophilic nature of acacia and Gambier bark which causes particle board to easily absorb water. Muhdi et al. (2013) examined the manufacture of particleboard from acacia wood waste with variable particle board material and adhesive type. From this research, it was concluded that the best is made from terraces with phenol-formaldehyde adhesive.

Table 1. SNI 03-2105-2006

\begin{tabular}{|c|c|c|c|}
\hline No & $\begin{array}{c}\text { Physical and mechanical } \\
\text { properties }\end{array}$ & Standard Value & Sample Size $(\mathrm{cm})$ \\
\hline 1 & Kerapatan $\left(\mathrm{g} / \mathrm{cm}^{3}\right)$ & $0.4-0.9$ & $10 \times 10$ \\
\hline 2 & Kadar air (\%) & Maks 14 & $10 \times 10$ \\
\hline 3 & Pengembangan tebal (\%) & Maks 12 & $5 \times 5$ \\
\hline 4 & $\begin{array}{l}\text { Modulus Elastisitas (MOE) } \\
\left(\mathrm{kgf} / \mathrm{cm}^{2}\right)\end{array}$ & Min $2.04 \times 10^{4}$ & $5 \times 20$ \\
\hline 5 & $\begin{array}{l}\text { Modulus Patah (MOR) } \\
\left(\mathrm{kgf} / \mathrm{cm}^{2}\right)\end{array}$ & Min 82 & $5 \times 20$ \\
\hline
\end{tabular}


Factors affecting the quality of particleboard:

a. Particle density.

The ratio between particle board density and wood density is around 1.3 so that the quality of the particleboard is good. According to Nababan (2017) the smaller density, the greater the thickness expansion value and if the density of the particle board is higher, the resulting MOR value will also be higher (Haygreen \& Bowyer, 1996).

b. Mixture types wood.

The flexural strength of particleboard depends on the mixture of wood species, the flexural strength of particleboard is better made from one type of wood.

c. Tree bark

The more bark in the wood particles the more properties of the particleboard aren't good because the bark will interfere with the bonding process between particles, the maximum amount of bark is around $10 \%$.

d. Adhesive

High levels of urea-formaldehyde adhesive will produce particle board with better flexural. According to Iskandar (2013), the higher the adhesive content so the higher the flexural strength value because the more adhesive will make the bond between particle board the better and the thickness expansion value will be smaller.

\section{e. Temperature}

The higher pressing temperature will increase the physical and mechanical properties of particleboard because the higher temperature given will result in high adhesion. After all, condensation reaction will be effective (Sumadiwangsa, 1986). According to Sudiyanto (2015), the higher temperature the water content of particleboard will decrease and the density value will increase because the more high pressing temperature will cause adhesive to react well and thicker swelling value will smaller.

Based on the scription above manufacture of particle board with adhesive tannins from mangrove bark is influenced by the pressing temperature and amount of adhesive added. This research aims to make particle board with tannins adhesive according to SNI standards and to find out the best amount of tannins and press temperature.

\section{Research Methods \\ Materials}

The materials used were mangrove bark from Surabaya beach, 96\% ethanol, teak sawdust wood from saradan district madiun east java, and formaldehyde.

\section{Tools}

The tools used in this research are a series of extraction tools, a series of hot presses for particleboard, oven, and sieve. 


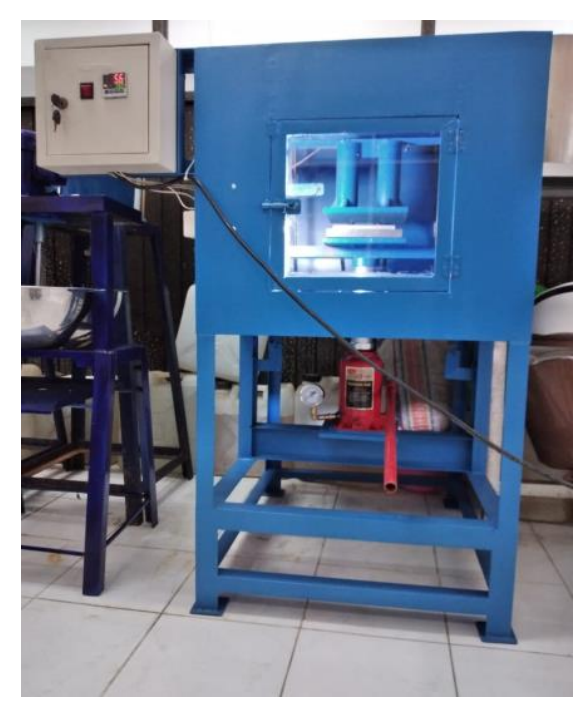

Figure 1. Hot Press particleboard

\section{Procedure}

Tannin extractions from mangrove bark

The mangrove bark that has been dried and crushed as much as 150 grams with a size of 40 mesh is put in a three-neck flask containing $750 \mathrm{ml}$ of ethanol solution with a concentration of $96 \%$. The extraction was Carried out at $70^{\circ} \mathrm{C}$ for 3 hours and then separated from the remaining mangrove bark powder and the filtrate is followed by a distillation process to remove ethanol so that a concentrated tannin solution is obtained.

\section{Making particle board with tannins adhesive}

Teak wood powders are dried in an oven then sieved with a size of 40 mesh and then mixed with tannin adhesive with an adhesive content according to the conditions being carried out $20 \%$, $25 \%, 30 \%$, and $35 \%$ of the weight of teak wood powder which has previously been added with $2 \%$ formaldehyde heavy teak sawdust and then to mixture was stirred until adhesive and teak sawdust were evenly mixed and then to continue with the pressing process in hot press with a temperature of 1100C, 1200C, 1300C and 1400C. This pressing process is carried out utilizing a particle board hot press obtain a solid and strong particleboard sheet, after pressing particle board was cooled at room temperature and then tested physically and mechanically so that it can be concluded whether it is following SNI standards.

\section{Results and Discussion}

Based on the research that has been done the following research are obtained:

\section{Water content}

Tabel II. Effect temperature and tannin addition on water concerns

\begin{tabular}{ccccc}
\hline Tannin Add & \multicolumn{4}{c}{ Water Conc (\%) } \\
\hline & $110^{\circ} \mathrm{C}$ & $120^{\circ} \mathrm{C}$ & $130{ }^{\circ} \mathrm{C}$ & $140^{\circ} \mathrm{C}$ \\
\hline $20 \%$ & $3,49 \%$ & $2,61 \%$ & $1,47 \%$ & $1,46 \%$ \\
$25 \%$ & $3,28 \%$ & $1,98 \%$ & $1,71 \%$ & $1,24 \%$ \\
$30 \%$ & $4,24 \%$ & $1,94 \%$ & $2,04 \%$ & $0,64 \%$ \\
& & & & \\
\hline
\end{tabular}




$35 \% \quad 4,07 \% \quad 1,87 \% \quad 1,63 \% \quad 1,62 \%$

Effect temperature and tannin addition on water concerns.

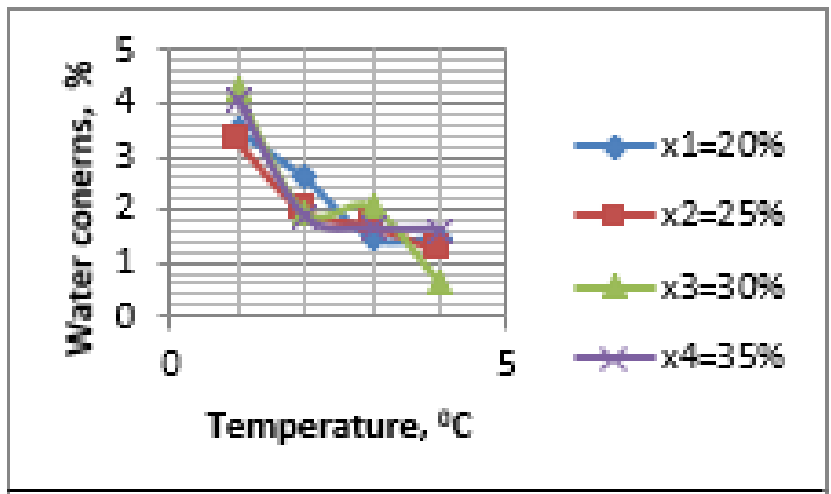

Figure 2. Effect Tannin on water concerns

From the results of research, it can be seen that pressing on heating and amount of tannin added is very influential and an average yield of water content at a temperature from $110^{\circ} \mathrm{C}$, $120^{\circ} \mathrm{C}, 130^{\circ} \mathrm{C}$, and $140^{\circ} \mathrm{C}$ obtained a moisture content of $3,77 \%, 2,10 \%, 1,71 \%$, and $1,24 \%$, while average yield of water content at tannin concentration of $20 \%, 25 \%, 30 \%$, and $30 \%$ was $2,25 \%$, $2,05 \%, 2,21 \%$, and $2,29 \%$. Based on the variation of pressing temperature it was found that the average value of water content decreased, this value was following SNI. It can be concluded that higher pressing temperature so lowers water content value because the higher temperature will accelerate the evaporation of water so that more water content was evaporated so the properties of the resulting particle board are getting better because of less water content.

\section{Density}

Tabel 3. Effect temperature and tannin added on bulk density

\begin{tabular}{ccccc}
\hline Tannin Added & \multicolumn{4}{c}{ Density $\left(\mathrm{gr} / \mathrm{cm}^{3}\right)$} \\
\hline & $110^{\circ} \mathrm{C}$ & $120^{\circ} \mathrm{C}$ & $130^{\circ} \mathrm{C}$ & $140^{\circ} \mathrm{C}$ \\
\hline $20 \%$ & 0,34 & 0,40 & 0,39 & 0,42 \\
$30 \%$ & 0,41 & 0,46 & 0,46 & 0,39 \\
$35 \%$ & 0,37 & 0,47 & 0,44 & 0,49 \\
& 0,37 & 0,49 & 0,46 & 0,46 \\
\hline
\end{tabular}

Effect Tannin Concerns on bulk density

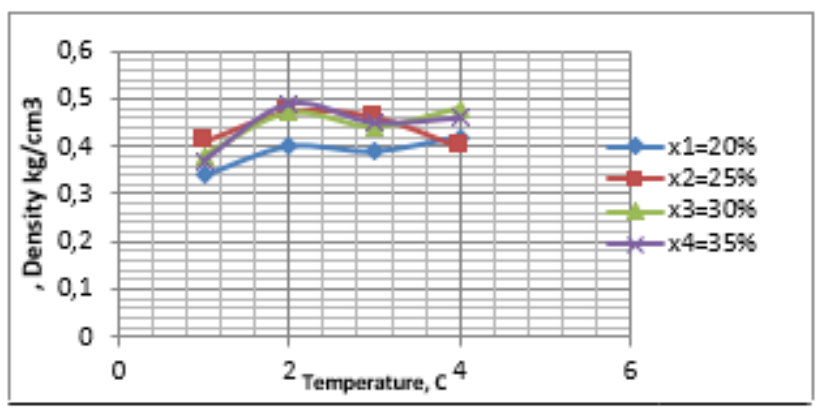

Figure 3. Effect tannin concern on density 
The result showed that heating temperature and tannin added were very influential, while average density obtained from the addition of $20 \%, 25 \%, 30 \%$, and $35 \%$ tannins was $0,38 \mathrm{gr} / \mathrm{cm}^{3}$, $0.43 \mathrm{gr} / \mathrm{cm}^{3}, 0.44 \mathrm{gr} / \mathrm{cm}^{3}$, and $0,44 \mathrm{gr} / \mathrm{cm}^{3}$, while average density results according to temperature. While the results of average density obtained from the addition of increasing tannins are following SNI, this increase in density is due to more tannin added will be able to close cavities of particle board so that weight increases which cause the density to increase. The density value obtained is following SNI, this is following Sudiyanto's research (2015) which states that an increase in density due to high temperatures supports a good adhesion process so it can be concluded that more amount of tannins used more cavities will be filled by adhesive and it will increase the total weight of particle board so that density of particleboard is getting bigger due to influence of adhesive which physically interacts with teak sawdust through cavities it filled. While the average density value is based on the variation of temperature of the press, the average value tends to get bigger due to the increase in density particle board. This value is following SNI and also this is following the opinion of Sudiyanto (2015) which states that increased density due to high temperature supports a good adhesion process.

\section{Thick develop}

Tabel 4. Effect temperature and tannin added on thick development

\begin{tabular}{|c|c|c|c|c|}
\hline \multirow[t]{2}{*}{ Tannin Add } & \multicolumn{4}{|c|}{ Thick Development (\%) } \\
\hline & $110^{\circ} \mathrm{C}$ & $120^{\circ} \mathrm{C}$ & $130^{\circ} \mathrm{C}$ & $140^{\circ} \mathrm{C}$ \\
\hline $20 \%$ & $15,75 \%$ & $20,40 \%$ & $19,17 \%$ & $15,26 \%$ \\
\hline $25 \%$ & $11,85 \%$ & $19,59 \%$ & $18,87 \%$ & $14,63 \%$ \\
\hline $30 \%$ & $\begin{array}{c}9,16 \\
\%\end{array}$ & $19,46 \%$ & $15,08 \%$ & $10,57 \%$ \\
\hline $35 \%$ & $\begin{array}{c}8,04 \\
\%\end{array}$ & $19,38 \%$ & $15,50 \%$ & $10,10 \%$ \\
\hline
\end{tabular}

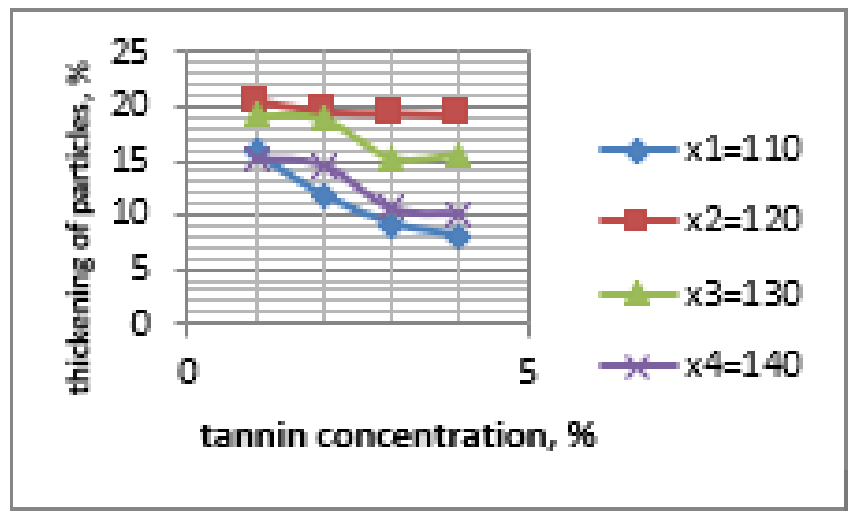

Figure 4. Effect Tannin concern on Thick develop

From research result it can be seen that pressing temperature and tannins addition greatly affect addition of particle board thickness and average heating temperature at $110^{\circ} \mathrm{C}, 120^{\circ} \mathrm{C}$, $130^{\circ} \mathrm{C}$ and $140^{\circ} \mathrm{C}$ is $11,2 \%, 19.71 \%, 17.16 \%$ and $12.64 \%$ while average yield based on variations in tannin addition at $20 \%, 25 \%, 30 \%$ and $35 \%$ is $17.65 \%, 16.24 \%, 13,57 \%$ and $13,26 \%$. This result can be concluded that greater pressing temperature used, smaller thickness expansion because 
high press temperature greatly supports bonding process. Meanwhile, the average thickness development value based on variation in the number of tannins tend to decrease, and this value accordance with SNI. It can be concluded that more increase in the amount of tannin so the smaller thickness expansion, more cavities will be covered and this will cause the density of particle board to be high, the height density value makes water not easy to get into the crack of the board.

\section{Flexural strength (MOR)}

Tabel 5. Effect temperature and tannin addition on flexural strength (MOR)

\begin{tabular}{ccccc}
\hline Tannin Add & \multicolumn{4}{c}{$(\mathrm{MOR})\left(\mathrm{kgf} / \mathrm{cm}^{2}\right)$} \\
\hline & $110^{\circ} \mathrm{C}$ & $\begin{array}{c}120^{\circ} \\
\mathrm{C}\end{array}$ & $\begin{array}{c}130^{\circ} \\
\mathrm{C}\end{array}$ & $140^{\circ} \mathrm{C}$ \\
\hline $20 \%$ & 3,83 & 5,12 & 1,95 & 5,81 \\
$25 \%$ & 5,17 & 9,31 & 8,15 & 2,62 \\
$30 \%$ & 4,76 & 12,13 & 6,85 & 7,29 \\
$35 \%$ & 0,48 & 14,06 & 10,32 & 8,59 \\
\hline
\end{tabular}

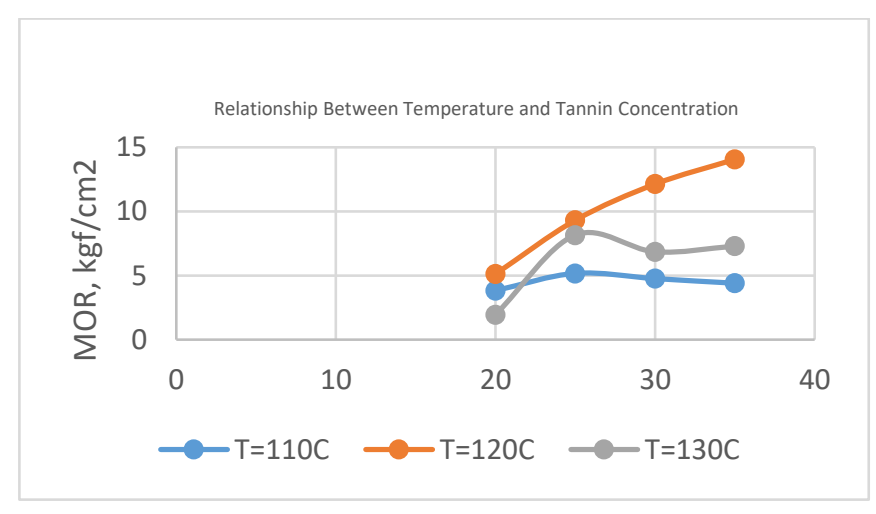

Figure 5. Effect Tannin concern on Flexural strength (MOR)

Result of flexural strength or MOR from variations in pressing temperature and tannin concentrations average value based on variation concentration at $20 \%, 25 \%, 30 \%$ and $35 \%$ respectively is $4.18 \mathrm{~kg} \mathrm{f} / \mathrm{cm} 2,6.32 \mathrm{~kg} \mathrm{f} / \mathrm{cm} 2,7.76 \mathrm{~kg} \mathrm{f} / \mathrm{cm} 2$ and $5.11 \mathrm{~kg} \mathrm{f} / \mathrm{cm} 2$. While average values obtained from variation of pressing temperature at $110^{\circ} \mathrm{C}, 120^{\circ} \mathrm{C}, 130^{\circ} \mathrm{C}$ and $140^{\circ} \mathrm{C}$ are $3.56 \mathrm{~kg}$ $\mathrm{f} / \mathrm{cm}^{2}, 7.66 \mathrm{~kg} \mathrm{f} / \mathrm{cm}^{2}, 6.06 \mathrm{~kg} \mathrm{f} / \mathrm{cm}^{2}$ and $6.08 \mathrm{~kg} \mathrm{f} / \mathrm{cm}^{2}$ respectively, based on pressing temperature at $120^{\circ} \mathrm{C}$ optimal MOR result was $7.66 \mathrm{~kg} \mathrm{f} / \mathrm{cm}^{2}$, while variation in amount of tannin added greater average value of MOR and optimal value was obtained at $30 \%$ tannin concentration $7.76 \mathrm{~kg} \mathrm{f} / \mathrm{cm}^{2}$, this isn't in accordance SNI.

Meanwhile based on a variation of temperature of press it's obtained that the average value of flexural strength (MOR) is getting bigger because condensation reaction will be able to take place effectively according to theory stated by Sumadiwangsa (1986) that thermosetting adhesives including tannin are sensitive to the effect of heat. The relationship between water content and MOR are inversely related, the smaller moisture content of particle board so greater MOR of particleboard. The relationship between density and MOR is directly proportional, greater density of particle board so greater than MOR. The relationship between thick swelling and MOR is inversely related, greater thickness expansion of particle board so smaller of MOR value of particleboard. 


\section{Conclusion}

Based on research data it can be concluded

1. Amount tannin and pressing temperature of the press are very influential on the physical properties of particleboard but less influence on mechanical properties of particleboard.

2. The best conditions obtained were at a temperature of $120^{\circ} \mathrm{C}$ and a concentration of $30 \%$ tannin obtained $1.87 \%$ moisture content, density $0.49 \mathrm{~g} / \mathrm{cm}^{3}$, and $19.38 \%$ thick expansion.

3. Based on the pressing temperature maximum average value for bending strength or MOR at $120^{\circ} \mathrm{C}$ is $7.66 \mathrm{~kg} \mathrm{f} / \mathrm{cm}^{2}$, this value isn't following SNI.

4. Based on the concentration of tannin, the maximum average value for MOR at a concentration of $30 \%$ tannin is $7.76 \mathrm{~kg} \mathrm{f} / \mathrm{cm}^{2}$, this value is still not following SNI

\section{References}

Amidah. (2006). Yield dan Tannin concern mangrove wood bark (Rhizopora mucronata Lamck) from Takisung area. Jurnal Hutan Tropis Borneo,18, 11-19.

Danarto, Y. C., Prihananto, S. A., \& Pamungkas, Z. A. (2011). Utilization tannin from mangrove wood bark as gugus fenol change on resin fenol formaldehid, Prosiding Seminar Nasional Teknik Kimia "Kejuangan". Yogyakarta.

Fathanah. (2013). particle Board product from Tandan Kosong Sawit with Acacia bark adhesive and Gambir. Jurnal Rekayasa Kimia dan Lingkungan, 9(3), 137-143.

Haygreen, J. G., \& Bowyer. J. L. (1996). Forest product and wood science. Yogyakarta: Gadjah Mada Unversity Press.

Iskandar. (2013). Effect Adhesive concern to Particle board properties Tofu bagasse (The Effect of Adhesive Content on Properties Bagasse of Particleboard). Jurnal Penelitian Hasil Hutan, 31(1), 119-225.

Lempang, M. (2016). Utilization Lignin as Wood Adhesive. Info Teknis EBONI, 13(2), 139-150.

Muhdi, Risnasari I., \& Putri L. A. P. (2013). Making particle board Study from Acacia wood waste. Life Sciences and physical Journal, 15(1), 115-120.

Nababan, M. (2017). Pressing temperature effect to physical and mechanical properties particle board used mixed Urea Formaldehida adhesive and Isosianat. Departemen Teknologi Hasil Hutan Fakultas Kehutanan Universitas Sumatera Utara.

Oka. (2005). Adhesive analysis on Making Petung bamboo limited block. Journal l SMAR Teknologi, 3(2), 93 - 100.

Paridah, M. T., \& Musgrave, O, C. (2006). Alkaline Treatment of Sulfited Tannin-Based Adhesive from Mangrove to Increase Bond Integrity of Beech Slips, Journal of Tropical Forest Science, 18(2), 137 - 143

Purnobasuki, H. (2004). Mangrove potency as Medicinal plant. Biota, IX (2), 125 -126.

Ruhendry. (2013). Liquid Adhesive development and Particle board from empty palm bunches waste. Jurnal Ilmu Pertanian Indonesia (JIPI).

SNI. (2006). SNI 03-2105-2006 Particle board quality. Badan Standardisasi Nasional. Jakarta.

Sudiryanto, G. (2015). Temperature and time pressing Effect to physical and mechanical properties particle board pinang wood (Paraserienthes Falcataria wood (L) Nielson). DISPROTEK Journal, 6(1), 1-10.

Suhendry. (2017). Extract characteristic from mangrove wood with different solution. Tropic forest Journal 1(2), 163-173.

Sumadiwangsa, S. (1986). Sawdust mangrove as Particle board adhesive Forest Products Research Journal, 2(4), 1-7.

Suseno. (2014). Ekstraksi tannin extraction from Pinus wood bark as Briquettes adhesive, niversitas Surabaya. 